\title{
An Introductory Bibliography for the Study of 1 Enoch*
}

\author{
HENRYK DRAWNEL, SDB \\ Institute of Biblical Studies, the John Paul II Catholic University of Lublin, Poland \\ e-mail: hdrawnel@kul.pl \\ ORCID: 0000-0003-4425-315X
}

\begin{abstract}
The article contains elementary information concerning the manuscripts of 1 Enoch, their editions, and scientific literature that deals with the topic. The presentation begins with the list of larger bibliographic collections concerning the Enochic writings, then the Aramaic witnesses preserved in 11 manuscripts found in Qumran Cave 4 are shortly discussed and pertinent information concerning their edition is given. The rest of the study adduces basic details about the manuscripts that contain the translation of the original Aramaic and the history of their publication. By offering a general perspective on the manuscripts of 1 Enoch, with special attention focused on Aramaic evidence, the article leads the reader through the textually and linguistically complicated history of text transmission of this important Jewish composition.
\end{abstract}

KEYWORDS: 1 Enoch, bibliography, manuscripts of 1 Enoch, critical editions, early Judaism, Jewish apocalyptic literature

\section{Bibliographic Collections}

Black, M. "A Bibliography on 1 Enoch in the Eighties." JSP 5 (1989): 3-16.

Coleman, G. B. "The Phenomenon of Christian Interpolations into Jewish Apocalyptic Texts: A Bibliographical Survey and Methodological Analysis." (PhD diss., Vanderbilt University; Nashville, TN, 1976), 62-86, 182-238.

DiTommaso, L. A Bibliography of Pseudepigrapha Research 1850-1999. JSPSup 39 (Sheffield: Sheffield Academic Press, 2001), 355-430.

Ehrenkrook, J. von. "The Parables of Enoch and the Messiah Son of Man: A Bibliography, 1773-2006." Pages 513-39 in Enoch and the Messiah Son of Man: Revisiting the Book of Parables. Edited by G. Boccaccini (Grand Rapids, MI: Eerdmans, 2007).

Ellens, J. H. "Bibliography." Hen 24 (2002): 235-54.

García Martínez, F., and E. J. C. Tigchelaar. "1 Enoch and the Figure of Enoch: A Bibliography of Studies 1970-1988.” RevQ 14 (1989): 149-74.

* The National Science Centre, Poland, has funded this project on the basis of the decision Dec2013/09/B/HS1/00728. 
Haelewyck, J.-C. Clavis apocryphorum Veteris Testamenti (Turnhout: Brepols, 1998), 35-42, 53.

Lehnardt, A. Bibliographie zu den jüdischen Schriften aus hellenistisch-römischer Zeit. JSHRZ 6/2 (Gütersloh: Gütersloher Verlagshaus, 1999), 423-447.

Rosso Ubigli, L. "Gli apocrifi (o pseudepigrafi) dell'Antico Testamento: Bibliografia 1979-1989." Hen 12 (1990): 259-321.

The Orion Center for the Study of the Dead Sea Scrolls and Associated Literature. Bibliography (http://orion.mscc.huji.ac.il/).

Waddell, J. "Enoch and the Enoch Tradition: A Bibliography, 2000-Present." Pages 337-47 in The Early Enoch Literature. Edited by G. Boccaccini and J. J. Collins. JSJSup 121 (Leiden: Brill, 2007).

\section{Editions of the Texts ${ }^{1}$}

Abegg, M. G., and J. E. Bowley et al. The Dead Sea Scrolls Concordance: Volume One: The Non-Biblical Texts from Qumran. 2 vols. (Leiden/Boston: Brill, 2003), 2:773-946. (Concordance of the Aramaic Dead Sea scrolls)

Coblentz Bautch, K., and A. Wright, eds. "5. Enoch." The Textual History of the Bible: Vol 2: Deutero-Canonical Scriptures. Edited by M. Henze (Leiden: Brill, forthcoming; cf. Brill Online Reference Works). (A comprehensive presentation of available manuscripts of 1 Enoch)

The Leon Levi Dead Sea Scrolls Digital Library (https://www.deadseascrolls. org.il/home). (Photographs of the Dead Sea manuscripts online)

\subsection{Aramaic Fragments}

Table 1. Aramaic manuscripts of 1 Enoch from Qumran ${ }^{2}$

\begin{tabular}{|l|l|l|l|l|l|}
\hline No. & Manuscript & \multicolumn{1}{|c|}{ Script } & \multicolumn{1}{|c|}{ Date } & \multicolumn{1}{c|}{$\begin{array}{c}\text { Number of } \\
\text { fragments }\end{array}$} & \multicolumn{1}{|c|}{ Enoch $^{\mathbf{3}}$} \\
\hline 1 & $4 \mathrm{Q} 201$ & $\begin{array}{l}\text { Semi-cursive, } \\
\text { archaic/early } \\
\text { Hasmonean }\end{array}$ & $\begin{array}{l}\text { Early first half } \\
\text { of the 2nd } \\
\text { c. BC }\end{array}$ & 24 & $1-5 ; 6-9$ \\
\hline
\end{tabular}

1 The manuscript sigla used in this bibliographic study are taken from H. Drawnel, Qumran Cave 4: The Aramaic Books of Enoch: 4Q201, 4Q202, 4Q204, 4Q205, 4Q206, 4Q207, 4Q212 (Oxford: Oxford University Press, 2019).

2 Since Qumran manuscripts are fragmentary, the chapter reference cited in the column in each case denotes a partial overlapping with the text of the $G \partial^{\prime} \partial z$ version. The chapter list has an indicative character so that the references to the verses in a given chapter have been omitted. 


\begin{tabular}{|c|c|c|c|c|c|}
\hline 2 & 4Q202 & $\begin{array}{l}\text { Semi- } \\
\text { cursive, early } \\
\text { Hasmonean }\end{array}$ & $\begin{array}{l}\text { The first half/ } \\
\text { middle of the } \\
\text { 2nd c. BC }\end{array}$ & 39 & $5-10 ; 14 ; 22$ \\
\hline 3 & 4Q204 & $\begin{array}{l}\text { formal, early } \\
\text { Herodian }\end{array}$ & $\begin{array}{l}\text { End of the } 1 \text { st } \\
\text { c. BC }\end{array}$ & 29 & $\begin{array}{l}1-6 ; 10 ; 12 ; \\
13-14 ; 15(?) \\
18 ; 30-32 \\
35-36 ; 89 \\
104-107\end{array}$ \\
\hline 4 & 4Q205 & $\begin{array}{l}\text { formal, early } \\
\text { Herodian }\end{array}$ & $\begin{array}{l}\text { End of the } \\
1 \text { st c. BC }\end{array}$ & 8 & $22-27 ; 89$ \\
\hline 5 & 4Q206 & $\begin{array}{l}\text { formal, late } \\
\text { Hasmonean/ } \\
\text { early Herodian }\end{array}$ & $\begin{array}{l}\text { Middle of the } \\
1 \text { st c. BC }\end{array}$ & 16 & $\begin{array}{l}14 ; 21 ; 22 ; \\
28-29 ; \\
31-34 ; 88-89\end{array}$ \\
\hline 6 & 4Q207 & $\begin{array}{l}\text { Semiformal, } \\
\text { early } \\
\text { Hasmonean }\end{array}$ & $150-125 \mathrm{BC}$ & 1 & 86 \\
\hline 7 & 4Q208 & $\begin{array}{l}\text { Semiformal, } \\
\text { archaic/early } \\
\text { Hasmonean }\end{array}$ & $\begin{array}{l}\text { End of the } 3 \mathrm{rd} / \\
\text { beginning of } \\
\text { the } 2 \mathrm{nd} \mathrm{c.} \mathrm{BC}\end{array}$ & 37 & $\overline{\text { cf. } 73: 4-8}$ \\
\hline 8 & 4Q209 & $\begin{array}{l}\text { Formal, early } \\
\text { Herodian }\end{array}$ & $\begin{array}{l}\text { 2nd half of the } \\
\text { 1st c. BC. }\end{array}$ & 41 & $\begin{array}{l}\text { Cf. 73:4-8; } \\
76-77 \text { (frgs. } \\
23+24) ; \\
78 \text { (?); } 79 \\
\text { (frg. 26); } 82 \\
\text { (frg. 28) }\end{array}$ \\
\hline 9 & 4Q210 & $\begin{array}{l}\text { Semi- } \\
\text { formal, late } \\
\text { Hasmonean }\end{array}$ & $\begin{array}{l}\text { Middle of the } \\
1 \text { st c. BC }\end{array}$ & 5 & $76-78$ \\
\hline 10 & 4Q211 & $\begin{array}{l}\text { Formal, late } \\
\text { Hasmonean }\end{array}$ & $\begin{array}{l}\text { 2nd half of the } \\
1 \text { st c. BC }\end{array}$ & 2 & $\overline{82: 20 ?}$; after \\
\hline 11 & 4Q212 & $\begin{array}{l}\text { Cursive, late } \\
\text { Hasmonean }\end{array}$ & $\begin{array}{l}\text { Middle of the } \\
\text { 1st c. BC }\end{array}$ & 6 & $91-94$ \\
\hline
\end{tabular}

\section{Editio princeps}

Milik, J. T. "Hénoch au pays des aromates (ch. XXVII à XXXII): Fragments araméens de la grotte 4 de Qumrân.” $R B 65$ (1958): 70-77. (4Q204 frg. 14 i-ii; 4Q206 frg. 4; 4Q209 frg. 23 6-9). Reprinted in J. A. Fitzmyer and D. J. Harrington. A Manual of Palestinian Aramaic Texts: (Second Century BC-Sec- 
ond Century AD). BibOr 34 (Rome: Biblical Institute Press, 1978), 64-68, 199-200.

Milik, J. T., with the collaboration of Matthew Black. The Books of Enoch: Aramaic Fragments of Qumrân Cave 4 (Oxford: Clarendon, 1976), 139-297, pl. I-XXX. Reviews: P. Grelot, RB (1976): 605-18; J. Barr, JTS (1978): 517-30; G. W. E. Nickelsburg, CBQ (1978): 411-19; J. C. VanderKam, JAOS 100 (1980): 360-62; etc.

Stuckenbruck, L. "4Q201 2-8." Pages 3-7, pl. I, in Qumran Cave 4 - XXVI: Cryptic Texts and Miscellanea, Part 1. In consultation with James Vanderkam and Monica Brady. Edited by S. J. Pfann et al. DJD 36 (Oxford: Clarendon, 2000).

Tigchelaar, E. J. C., and F. García Martínez. “4QAstronomical Enoch ${ }^{\mathrm{a}-\mathrm{b}}$ ar.” Pages 95-171, pl. III-VII, in Qumran Cave 4 - XXVI: Cryptic texts And Miscellanea, Part 1. In consultation with James Vanderkam and Monica Brady. Edited by S. J. Pfann et al. DJD 36 (Oxford: Clarendon, 2000).

\section{Subsequent Editions}

Beyer, K. “(1Q19).4Q201-207.4QEnastra-d: Henoch.” Pages 225-258 in Die aramäischen Texte vom Toten Meer samt den Inschriften aus Palästina, dem Testament Levis aus der Kairoer Genisa, der Fastenrolle und den alten talmudischen Zitaten (Göttingen: Vandenhoeck \& Ruprecht, 1984).

Drawnel, H. The Aramaic Astronomical Book (4Q208-4Q211), from Qumran: Text, Translation, and Commentary (Oxford: Oxford University Press, 2011), Pl. I-VIII. Review: P. Foster, ExpTim 123 (2011): 140-41; H. Tervanotko, HS 53 (2012): 401-4; S. Crawford White, $C B Q 74$ (2012): 788-90; J. C. VanderKam, DSD 20 (2013): 326-328.

Drawnel, H. Qumran Cave 4: The Aramaic Books of Enoch: 4Q201, 4Q202, 4Q204, 4Q205, 4Q206, 4Q207, 4Q212 (Oxford: Oxford University Press, 2019), ch. 2, pl. I-XVII. (Aramaic text paralleled with existing versions; Aramaic concordance; Aramaic-Greek, Greek-Aramaic concordances)

García Martínez, F., and E. J. C. Tigchelaar. The Dead Sea Scrolls Study Edition (Leiden: Brill, 2000), 399-409, 412-445.

Langlois, M. Le premier manuscript du Livre d'Hénoch: Étude épigraphique et philologique des fragments araméens de 4Q201 à Qumrân. Lectio divina, hors série (Paris: Cerf, 2008).

Parry, D. W., and E. Tov, in association with G. I. Clements. The Dead Sea Scrolls Reader. 2 vols. 2nd ed., rev. and exp. (Leiden: Brill, 2014), 1:920-937, 967-972, 1001-1019. Review: M. Weigold, DSD 15 (2008): 397-400. 


\section{Studies}

Black, M. "The Fragments of the Aramaic Enoch from Qumran.” Pages 15-28 in La littérature juive entre Tenach et Mischna: Quelques problèmes. Edited by W. C. Van Unnik. RechBib 9 (Leiden: E.J. Brill, 1974).

Davis, Kipp et al. "Nine Dubious 'Dead Sea Scrolls' Fragments from the Twenty-First Century." DSD 24 (2017): 1-40, see esp. 17-21 (MS 4612/6, 1 En. 106:19-107: 1), 21-25 (MS 4612/8, 1 En. 7:1-5), 28-32 (MS 4612/12=XQpapEnoch, 1 En. 8:4-9:3): three Enoch mss. from Schøyen collection recognized as modern forgeries.

Eshel E., and H. Eshel. “XQpapHen.” Tarbiz 73 (2004): 171-79 (in Hebrew).

Eshel, E., and H. Eshel. "New Fragments from Qumran: 4QGen", 4QIsa ${ }^{\mathrm{b}}$, 4Q226, 8QGen, and XPapEnoch." DSD 12 (2005): 134-57.

Langlois, M. "Un manuscrit araméen inédit du livre d'Hénoch et les versions anciennes de 1 Hénoch 7,4." Sem 55 (2013): 101-16. (Schøyen collection, MS $4612 / 8$, modern forgery)

Olson, D. C. "Recovering the Original Sequence of 1 Enoch 91-93." JSP 11 (1993): 69-94.

Puech, É. "Notes sur le manuscript araméen 4Q201 = 4QHénoch ${ }^{\mathrm{a}}$. À propos d'un livre récent." $\operatorname{Rev} Q 24$ (2010): 627-49. (A review of M. Langlois, Le premier manuscript du Livre d'Hénoch, with new readings of 4Q201)

Sokoloff, M. "Notes on the Aramaic Fragments of Enoch from Qumran Cave 4." Maarav 1 (1978-79): 197-224. (Corrections and improvements of some of Milik's [1976] readings and translations, with a provisional dictionary)

Stuckenbruck, L. "Revision of Aramaic-Greek and Greek-Aramaic Glossaries in The Books of Enoch: Aramaic Fragments of Qumrân Cave 4 by J. T. Milik." JJS 41 (1990): 13-48.

Stuckenbruck, L. "The Early Traditions Related to 1 Enoch from the Dead Sea Scrolls: An Overview and Assessment." Pages 41-63 in The Early Enoch Literature. Edited by G. Boccaccini and J. J. Collins. JSJSup 121 (Leiden: Brill, 2007).

Tigchelaar, E. J. C. "Evaluating the Discussions concerning the Original Order of Chapters 91-93 and Codicological Data Pertaining to 4Q212 and Chester Beatty XII Enoch.” Pages 220-23 in Enoch and Qumran Origins: New Light on a Forgotten Connection. Edited by G. Boccaccini (Grand Rapids, MI: Eerdmans, 2005).

Tigchelaar, E. J. C. "A Provisional List of Unprovenanced, Twenty-First Century, Dead Sea Scrolls-like Fragments." DSD 24 (2017): 173-88.

Tov, E. "4QGenealogical List?" Page 290, Pl. XIX in Qumran Cave 4 - XXVI: Cryptic texts and Miscellanea, Part 1. In consultation with James Vanderkam and Monica Brady. Edited by S. J. Pfann et al. DJD 36 (Oxford: Clarendon, 2000). (Verso side of 4Q201 frg. 3.) 


\subsection{Q19, 1Q19bis - Hebrew Fragments related to 1 Enoch}

1Q19, 19bis (frg. 2); formal, early Herodian hand, end of the 1st c. BC; 21 fragments; frgs. 1-2 (cf. 1 En. 8:4-9:4), frg. 3 (cf. ch. 106).

\section{Editio princeps}

Barthélemy, D., OP, and J. T. Milik. Qumran Cave I: With Contributions by Roland de Vaux, OP, G. M. Crowfoot, H. J. Plenderleith, G. L. Harding. DJD 1 (Oxford: Clarendon Press, 1955) 84-86, pl. XVI; frg. 19bis, p. 152 (no plate). (The fragmentary text considered by Milik as one of the sources of 1 Enoch)

\section{Studies}

Beyer, K. Die aramäischen Texte vom Toten Meer samt den Inschriften aus Palästina, dem Testament Levis aus der Kairoer Genisa, der Fastenrolle und den alten talmudischen Zitaten (Göttingen: Vandenhoeck \& Ruprecht, 1984), 229 and n. 1. (Considers the Hebrew fragments to be part of the text of 1 Enoch originally written in Hebrew.)

García Martínez, F. Qumran and Apocalyptic: Studies on the Aramaic Texts from Qumran. STDJ 9 (Leiden: E. J. Brill, 1992), 42.

Milik, J. T. "The Dead Sea Scrolls fragment of the Book of Enoch.” Bib 32 (1951): 393-400. (1Q19 frg. 3 with a commentary)

Milik, J. T. with the collaboration of Matthew Black. The Books of Enoch: Aramaic Fragments of Qumrân Cave 4 (Oxford: Clarendon, 1976), 55.

Milik, J. T. "Écrits préesséniens de Qumrân: d'Hénoch à Amram." Pages 94-95 in Qumrân: Sa piété, sa théologie et son milieu. Edited by M. Delcor. BETL 46 (Paris: Duculot; Leuven: University Press, 1978).

Stuckenbruck, L. The Book of Giants from Qumran: Texts, Translation, and Commmentary. TSAJ 63 (Tübingen: Mohr Siebeck, 1997), 217-18.

Trever, J. C. "Completion of the Publication of some Fragments from Qumran Cave I." RevQ 5 (1965): 323-44, esp. 334, pl. VIIb.

\subsection{Greek Versions}

Barr, J. "Aramaic-Greek Notes on the Book of Enoch (I)." JSS 23 (1978): 184-198. Barr, J. “Aramaic-Greek Notes on the Book of Enoch (II).” JSS 24 (1979): 179-192. 
Bauer, J. B. "Index verborum in libris pseudepigraphis usurpatorum: Fragmenta Graeca libri Henoch." Pages 515-556 in Clavis librorum Veteris Testamenti apocryphorum philologica. C. A. Wahl. (Leipzig: Johannes Ambrosius Barth, 1853; repr. Graz: Akademischer Druck- und Verlagsanstalt, 1972).

Black, M. "Appendix B: Apocalypsis Henochi graece: Addenda et corrigenda." Pages 419-22 in The Book of Enoch or I Enoch: A New English Edition with Commentary and Textual Notes (SVTP 7 (Leiden: Brill, 1985). (Corrections of the Greek text of the Panopolitanus, Syncellos, P. Oxy. XVII 2069, P. Chester Beatty XII)

Denis, A.-M. Concordance grecque des Pseudoépigraphes d'Ancien Testament (Louvain-la-Neuve: Université Catholique de Louvain, Institut Orientaliste, 1987).

Larson, E. W. The Translation of Enoch: From Aramaic into Greek. JSJSup 53 (Leiden: Brill, 1997).

Larson, E. W. "The Relation between the Greek and Aramaic Texts of Enoch." Pages 434-44 in Dead Sea Scrolls: Fifty Years after their Discovery: Proceedings of the Jerusalem Congress, July 20-25, 1997. Edited by L. H. Schiffman, E. Tov, and J. C. VanderKam (Jerusalem: Israel Exploration Society, 2000).

Milik, J. T., with the collaboration of Matthew Black. The Books of Enoch: Aramaic Fragments of Qumrân Cave 4 (Oxford: Clarendon, 1976), 70-78.

Torrey, C. C. "Notes on the Greek Texts of Enoch." JAOS 62 (1942): 52-60.

Zuntz, G. "Notes on the Greek Enoch." JBL 61 (1942): 193-204.

\subsubsection{Codex Cairensis 10759}

$\mathbf{G}^{\mathbf{C}}$ - Cairensis 10759 An uncial parchment codex found at Akhmīm (ancient Panopolis), Egypt; 33 folios (66 pages); 6th c.; Egyptian Museum, Cairo. (Except for the Greek text of the book of the Watchers, it also contains one section of the Gospel of Peter, Apocalypse of Peter, and a fragment of the Acts of St. Julian.) $\mathbf{G}^{\mathbf{C}-1}-$ ff. $11 \mathrm{r}-25 \mathrm{v}$ (pp. 21-50) (19:3; 20:2-21:9; 1:1-14:22a); first copyist. $\mathbf{G}^{\mathrm{C}-2}-$ ff. $26 \mathrm{r}-33 \mathrm{v}$ (pp. 51-66) (14:22b-32:6); second copyist.

\section{Editio princeps}

Bouriant, U. "Fragments du texte grec du livre d'Énoch et de quelques écrits attribués à saint Pierre." Pages 91-147 in Le papyrus mathématique d'Akhmîm - Fragments du texte grec du livre d'Énoch et de quelques écrits attribués 
à saint Pierre. Edited by J. Baillet and U. Bouriant. MPMMAFC 9/1 (Paris: Ernest Leroux, 1892). (It contains transcription errors.)

Lods, A. Reproduction en héliogravure du manuscrit d'Énoch et des écrits attribués à Saint Pierre (MPMMAFC 9/3 (Paris: Ernest Leroux, 1893). (Enoch: Pl. XI-XXXIII; pp. 230-232: correction of Bouriant's transcription errors)

\section{Subsequent Editions and Studies}

Bauckham, R. J. "A Note on a Problem in the Greek Version of 1 Enoch i.9.” JTS 32 (1981): 136-38.

Black, M., and A.-M. Denis. Apocalypsis Henochi Graece - Fragmenta Pseudepigraphorum Quae Supersunt Graeca. PVTG 3 (Leiden: E. J. Brill, 1970), 3-44.

Burkitt, F. C. "Appendix I: On the Greek Text of Enoch.” Pages 53-71 in Jewish and Christian Apocalypses: The Schweich Lectures 1913 (London: Oxford University Press, 1914).

Charles, R. H. The Book of Enoch Translated from Professor Dillmann's Ethiopic Text (Oxford: Clarendon Press, 1893), 318-70.

Charles, R. H. The Ethiopic Version of the Book of Enoch Edited from TwentyThree MSS, together with the Fragmentary Greek and Latin Versions. Anecdota Oxoniensia. Semitic Series 11 (Oxford: Clarendon Press, 1906), 3-75.

Charles, R. H. The Book of Enoch or 1 Enoch: Translated from the Editor's Ethiopic Text (Oxford: Clarendon Press, 1912), 273-304.

Dillmann, A. "Über den neugefundenen griechischen Text des Henoch-Buches." Sitzungsberichte der königlisch Preussischen Akademie der Wissenschaften zu Berlin 51, 53 (1892): 1039-54, 1079-92.

Flemming, J., and L. Radermacher. Das Buch Henoch. GCS 5 (Leipzig: Hinrich, 1901), 18-60.

Lods, A. Le livre d'Hénoch: Fragments grecs découverts ŕ Akhmîm (Haute-Égypte) publiés avec les variantes du texte éthiopien (Paris: Ernest Leroux, 1892).

Swete, H. B. The Old Testament in Greek according to the Septuagint. 3 vols. 2nd ed. Cambridge: University Press, 1899), 3:789-808.

Swete, H. B. The Psalms of Solomon with the Greek Fragments of the Book of Enoch (Cambridge: Cambridge University Press, 1899), 25-44.

\subsubsection{Two Excerpts in George Syncellos' Chronography}

$\mathbf{G}^{\mathbf{S}-1}$ - first insertion: $6: 1-7: 2 ; 8: 1-9: 4 ; \mathbf{G}^{\mathbf{S}-2}-$ second insertion: 8:4-10:14; 15:8-16:1. 
George the Synkellos, an ecclesiastic assistant to the Patriarch of Constantinople Tarasius (AD 784 to 806), based his world history on a variety of ancient sources. The two large excerpts from the Book of the Watchers are probably drawn from the writings of Panodoros and Annianos, two Greek historians active in the early fifth century AD.

\section{Editio princeps}

Scaliger, J. J. Thesaurus temporum, Eusebii Pamphili Caesareae Palaestinae episcopi, chronicorum canonum omnimodae historiae libri duo, interprete Hieronymo (Leiden, 1606), 244-45.

Goar, J. Georgii Monachi ... quondam Syncelli Chronographia, ab Adamo usque ad Diocletianum. (Byzantinae Historiae Scriptores Uarii 5 (Paris: Typographie royale, 1652). (First full edition of the Chronicle)

\section{Subsequent Editions and Studies}

Adler, W., and P. Tuffin. The Chronography of George Synkellos: A Byzantine Chronicle of Universal History from the Creation (Oxford: Oxford University Press, 2002). (The first complete translation of the Chronography in a modern language, based on the Mosshammer edition)

Black, M., and A.-M. Denis. Apocalypsis Henochi Graece - Fragmenta Pseudepigraphorum Quae Supersunt Graeca. PVTG 3 (Leiden: E. J. Brill, 1970), 21-26, 29-30, 37.

Charles, R. H. The Ethiopic Version of the Book of Enoch Edited from TwentyThree MSS, together with the Fragmentary Greek and Latin Versions. Anecdota Oxoniensia. Semitic Series 11 (Oxford: Clarendon Press, 1906), 13-29, 43-47.

Charles, R. H. The Book of Enoch or 1 Enoch: Translated from the Editor's Ethiopic Text (Oxford: Clarendon Press, 1912), 277-87, 292-94.

Dindorf, W. Georgius Syncellus et Nicephorus Constantinopolitanus. 2 vols. CSHB 20-21 (Bonn: Weber, 1829), 1:20-23, 42- 47.

Flemming, J., and L. Radermacher. Das Buch Henoch (GCS 5 (Leipzig: Hinrich, 1901), 24-32, 42-45.

Mosshammer, A. A. Georgii Syncelli Ecloga chronographica. BSGRT (Leipzig: Teubner, 1984). (Modern critical edition of the Chronography together with an apparatus criticus and apparatus fontium. First insertion: pp. 11, 1. $19-$ p. 13, 1. 16 [§§ 20-23]; second insertion: p. 24, 1. 10 - p. 26, 1. 25 [§§ 43-47]) 
Swete, H. The Old Testament in Greek according to the Septuagint. 3 vols. 2nd ed. (Cambridge: University Press, 1899), 3:791-97, 801.

\subsubsection{Papyrus Oxyrhynchus 2069}

$G^{\text {Oxy }}-$ P. Oxy. XVII 2069 Five fragments of an uncial codex from Oxyrhynchus, Egypt; late 4th c. AD; Papyrology Room, Sackler Library, Oxford. Frg. $1 \mathrm{r}=85: 10-86: 2$; frg. $1 \mathrm{v}=87: 1-87: 2$; frg. $2 \mathrm{r}=86: 2$; frg. $2 \mathrm{v}=87: 3$.

Frgs. 3-5 were reconstructed by Milik (1971) as preserving the text of the Astronomical Book (frg. $3=77: 7-78: 1,8$; frg. $4=$ chs. $75-78$; frg. $5 r=79: 3$ or 4), but his identification has been questioned.

\section{Editio princeps}

Hunt, A. S. The Oxyrhynchus Papyri: Part XVII. GRM 20 (London: Egypt Exploration Society, 1927), 6-8. (Identified as part of an apocalyptic work)

\section{Subsequent Editions}

Black, M. The Book of Enoch or I Enoch: A New English Edition with Commentary and Textual Notes. SVTP 7 (Leiden: Brill, 1985), 420-21. (Frg. 3 and frg. 1)

Black, M., and A.-M. Denis. Apocalypsis Henochi Graece - Fragmenta Pseudoepigraphorum Quae Supersunt Graeca. PVTG 3 (Leiden: E. J. Brill, 1970), 233-34. (Not yet identified as part of 1 Enoch)

Drawnel, H. Qumran Cave 4. The Aramaic Books of Enoch. 4Q201, 4Q202, 4Q204, 4Q205, 4Q206, 4Q207, 4Q212 (Oxford: University Press, 2019), $\S$ 1.3.2.4, pl. XVIII-XIX. (Photographs published for the first time)

\section{Studies}

Milik, J. T. "Fragments grecs du Livre d'Hénoch (P. Oxy. XVII 2069)." CdE 46 (1971): 321-43. (He identified the fragments as making part of 1 Enoch.)

Chesnutt, R. D. "Oxyrhynchus Papyrus 2069 and the Compositional History of 1 Enoch.” JBL 129 (2010): 485-505. 


\subsubsection{Vat. Gr. 1809}

$\mathbf{G}^{\text {Vat }}$ - Vaticanus Graecus 1809, f. 216v, 11. 1-7a (89:42-49). A brachygraphic fragment in the Greek manuscript from the end of the 10th c. British Library, London.

\section{Editio princeps}

Mai, A. S. Cyrilli Alexandrini Commentarium in S. Lucae Evangelium nec non eiusdem alia opuscula XVI. Nova patrum bibliotheca 2 (Rome, 1844), iv. (Edition based on the manual transcription of the fragment)

Gildemeister, J. "Ein Fragment des griechischen Henoch.” ZDMG 9 (1855): 62124. (Text transcribed and commented upon, with errors)

\section{Subsequent Editions}

Drawnel, H. Qumran Cave 4: The Aramaic Books of Enoch: 4Q201, 4Q202, 4Q204, 4Q205, 4Q206, 4Q207, 4Q212 (Oxford: University Press, 2019), $\S$ 1.3.2.5, Pl. XX. (Photograph published for the first time)

Charles, R. H., The Book of Enoch Translated from Professor Dillmann's Ethiopic Text (Oxford: Clarendon Press, 1893), 238-40.

Charles, R. H. The Ethiopic Version of the Book of Enoch Edited from TwentyThree MSS, together with the Fragmentary Greek and Latin Versions. Anecdota Oxoniensia. Semitic Series 11 (Oxford: Clarendon Press, 1906), 175, 177. Gardthausen, V. "Zur Tachygraphie der Griechen.” Hermes 11 (1876): 443-57. Pl. 1-3. (Contains a description of the whole manuscript Vat. Gr. 1809 in Italian by G. Guidi [pp. 448-450])

Gitlbauer, M. Die Ueberreste griechischer Tachygraphie im Codex Vaticanus graecus 1809: Erster Fascikel, mit 14 Tafeln. DAWW 28/1 (Wien: Karl Gerold's Sohn, 1878). (Syllabic transcription, p. 57; critical text and notes with the correction of Gildemeister's transcription errors, pp. 94-95; pl. XI)

Swete, H. The Old Testament in Greek according to the Septuagint. 3 vols. 2nd ed. (Cambridge: University Press, 1899), 3:808-9.

\section{Studies}

Chionides, N. P. "Il sistema brachigrafico italo-bizantino." Pages 7-66 in La brachigrafia italo-bizantina. N. P. Chionides and S. Lilla. StT 290 (Città del Vaticano: Biblioteca Apostolica Vaticana, 1981). 
Lilla, S. Il testo tachigrafico del 'De divinis nominibus' (Vat. Gr. 1809). StT 263 (Città del Vaticano: Biblioteca Vaticana, 1970).

\subsubsection{Chester Beatty-Michigan Papyrus Codex}

$\mathbf{G}^{\mathbf{C M}}$ - P. Chester Beatty XII (Chester Beatty-Michigan), ff. 1v-6r (97:6104:13; 106:1-107:3). Part of a papyrus uncial codex from Egypt dated to the early 4th c.; Chester Beatty Library, Dublin, Ireland and the University of Michigan Library, Ann Arbor, MI, USA. The papyrus codex also contains the Homily on the Passion by Melito of Sardis and fragmentary Ezekiel Apocryphon.

\section{Editio princeps}

Bonner, C., with the collaboration of H. C. Youtie. The Last Chapters of Enoch in Greek. SD 8 (London: Christophers, 1937).

Kenyon, F. G. The Chester Beatty Biblical Papyri: Descriptions and Texts of Twelve Manuscripts on Papyrus of the Greek Bible. Fasciculus VIII. Enoch and Melito. Plates (London: Emery Walker, 1941).

\section{Subsequent Editions and Studies}

Black, M., and A.-M. Denis. Apocalypsis Henochi Graece - Fragmenta Pseudepigraphorum Quae Supersunt Graeca. PVTG 3 (Leiden: E. J. Brill, 1970), 37-44.

Bonner, C. The Homily on the Passion by Melito, Bishop of Sardis, with Some Fragments of the Apocryphal Ezekiel. SD 12 (London: Christophers, 1940).

Jeremias, J. "Ein neuer Textfund: Das Henochfragment der Chester-Beatty-Papyri." TBl 18 (1939): 145-46.

Jeremias, J. "Beobachtungen zu neutestamentlichen Stellen an Hand des neugefundenen griechischen Henoch-Textes." ZNT 38 (1939): 115-24.

Larson, E. W. "The Translation of Enoch: From Aramaic into Greek" (PhD diss., New York University, 1995), 170-172.

Nickelsburg, G. W. E. "Enoch 97-104: A Study of the Greek and Ethiopic Texts." Pages 90-156 in Armenian and Biblical Studies. Edited by M. E. Stone (Jerusalem: St. James Press, 1976).

Pietersma, A. Chester Beatty Biblical Papyri IV and V: A New Edition with TextCritical Analysis. ASP 16 (Toronto: S. S. Hakkert, 1977). 
Pietersma, A. "The New Greek Fragments of Biblical Manuscripts in the Chester

Beatty Library." BASP 24 (1987): 37-61. (Additional fragments of 1 Enoch in

P. Chester Beatty XII, pp. 40-45; pl. 1-4, pp. 50-51, 52-53; ch. 93 [end of the chapter, f. 5v] and 94:7-8 [f. 5r]; 100:1-2 [f. 3v] and 100:10-11 [f. 3r]) Zuntz, G. "The Greek Text of Enoch 102. 1-3.” JBL 63 (1944): 53-54.

\subsubsection{Greek Papyrus from Cave 7}

7QEn gr - 7Q4, 7Q8, 7Q11, 7Q12, 7Q13, 7Q14. Papyrus fragmentary scroll dated between 1st c. BC and first half of the 1st c. AD. 7Q4 1+7Q12+7Q14 (col. i) $=103: 7-8 ; 7 \mathrm{Q} 8($ col. ii $)=103: 7-8$ 7; 7Q11 $=100: 12 ; 7 Q 13=103: 15$ (?).

J. O'Callaghan interpreted 7Q4 and 7Q8 as containing 1 Tim 3:16-4:1, 3 and Jas 1:23-24 respectively. The proposal has been rejected on paleographic grounds and the identification with the Epistle of Enoch has been proposed by Nebe, Muro, and Puech.

\section{Editio princeps}

Baillet, M., J. T. Milik, and R. d. Vaux, avec une contribution de H. W. Baker. Les 'Petites Grottes' de Qumrân: Exploration de la falaise; Les grottes 2Q, 3Q, $5 Q, 6 Q, 7 Q$ à 10Q. Le rouleau de cuivre. DJDJ 3 (Oxford: Clarendon Press, 1962), 143-46, pl. XXX.

\section{Subsequent Editions and Studies}

Muro, E. A. "The Greek Fragments of Enoch from Qumran Cave 7 (7Q4, 7Q8, \& 7Q12 = 7QEn gr = Enoch 103:3-4, 7-8).” RevQ 18 (1997): 307-12.

Nebe, G.-W. "7Q4 - Möglichkeit und Grenze einer Identifikation." RevQ 13 (1988): 629-33.

O’Callaghan, J. “¿Papiros neotestamentarios en la cueva 7 de Qumrān?” Bib 53 (1972): 91-100.

O’Callaghan, J. “¿1 Tim 3,16; 4,1.3 en 7Q4?” Bib 53 (1972): 362-67.

O'Callaghan, J. Los primeros testimonios del Nuevo Testamento. En los origenes del Cristianismo 7 (Córdova: Ediciones El Almendro, 1995).

Puech, É. "Des fragments grecs de la grotte 7 et le Nouveau Testament? 7Q4 et 7Q5, et le papyrus Magdalen grec $17=\mathrm{P}^{64} . " R B 102$ (1995): 570-584.

Puech, É. "Notes sur les fragments grecs du manuscript 7Q4 = 1 Hénoch 103 et 105.” $R B 103$ (1996): 592-600. 
Puech, É. "Sept fragments grecs de la Lettre d'Hénoch (1 Hén 100, 103 et 105) dans la grotte 7 de Qumrân (= 7QHéngr)." RevQ 18 (1997): 313-23.

Spottorno, M. V. "Can Methodological Limits Be Set in the Debate on the Identification of 7Q5?” DSD 6 (1999): 66-77.

\subsection{Ethiopic Version}

An ancient Ethiopic (Gəoz) version, presumably from Greek, contains the largest, although by no means exhaustive, portion of the Enochic literary tradition known only partially in Qumran Aramaic and later versions. The first manuscripts reached Europe in 1773, if not earlier. The text that is often corrupt is known in two recensions: Eth. I, more ancient and closer to the Cairensis 10759; Eth. II, later and reworked vulgate contained in inferior manuscripts, sometimes with valuable readings, though. Discovered in the 20th c., ms. Tânā 9 and HMML 2080 are counted among the best witnesses of Eth. I recension.

Table 2. Ethiopic manuscripts of 1 Enoch used in critical editions

\begin{tabular}{|l|l|l|l|l|l|l|}
\hline Rec. & Manuscript & $\begin{array}{l}\text { Dillmann } \\
\mathbf{1 8 5 1}\end{array}$ & $\begin{array}{l}\text { Flemming } \\
\mathbf{1 9 0 2}\end{array}$ & $\begin{array}{l}\text { Charles } \\
\mathbf{1 9 0 6}\end{array}$ & $\begin{array}{l}\text { Knibb } \\
\mathbf{1 9 7 8}\end{array}$ & $\begin{array}{l}\text { Tiller } \\
\mathbf{1 9 9 3}\end{array}$ \\
\hline II & $\begin{array}{l}\text { Oxf. Bodl. 4 } \\
\text { (Orient. 531), 40 ff., } \\
\text { 18th c.; 1-105 }\end{array}$ & A & A & a & Bodl 4 & a \\
\hline II & $\begin{array}{l}\text { Oxf. Bodl. 5, } \\
\text { ff. 1-32, 18th } \\
\text { c.; 1-98 }\end{array}$ & B & B & b & Bodl 5 & b \\
\hline II & $\begin{array}{l}\text { Frankfurt Or. } \\
\text { Rüppell II, 1, } \\
\text { pp. 1-52. 18th } \\
\text { c.; 1-98 }\end{array}$ & C & C & c & Frankfurt MS. & c \\
\hline II & $\begin{array}{l}\text { Br. Libr. Orient. } \\
8822 \text { (Curzon 55), } \\
\text { ff. 2ra-35rb, 18th } \\
\text { c.; 1-102 }\end{array}$ & D & D & d & Curzon 55 & d \\
\hline II & $\begin{array}{l}\text { Br. Libr. Orient. } \\
8823 \text { (Curzon 56), } \\
\text { ff. 3ra-22va, 18th } \\
\text { c.; 1-108 }\end{array}$ & E & E & e & Curzon 56 & e \\
\hline
\end{tabular}




\begin{tabular}{|c|c|c|c|c|c|}
\hline II & $\begin{array}{l}\text { Br. Libr. Add. } \\
24185 \text {, ff. 77, 19th } \\
\text { c.; } 1-106\end{array}$ & $\mathrm{~F}$ & $\mathrm{f}$ & BM Add. 24185 & $\mathrm{f}$ \\
\hline I & $\begin{array}{l}\text { Br. Libr. Orient. } \\
485 \text {, ff. } 102 \mathrm{r}-190 \mathrm{v}, \\
1 \text { st half of } 16 \text { th } \\
\text { c.; } 1-108\end{array}$ & G & g & BM 485 & $\mathrm{~g}$ \\
\hline I & $\begin{array}{l}\text { Br. Libr. Orient. } \\
485 \text {, ff. } 102 \mathrm{r}-190 \mathrm{v}, \\
\text { 1st half of } 16 \text { th c.; } \\
97: 6 \mathrm{~b}-108: 10\end{array}$ & & $1 \mathrm{~g}$ & $\mathrm{BM} 485 \mathrm{a}$ & \\
\hline II & $\begin{array}{l}\text { Br. Libr. Orient. } \\
484 \text {, ff. } 2 \text { r }-14 \text { r, } 18 \text { th } \\
\text { c.; } 1-108\end{array}$ & $\mathrm{H}$ & $\mathrm{h}$ & BM 484 & $\mathrm{~h}$ \\
\hline II & $\begin{array}{l}\text { Br. Libr. Orient. } \\
486 \text {, ff. } 1 \mathrm{r}-18 \mathrm{v}, 18 \mathrm{th} \\
\text { c.; } 60: 13 \mathrm{~b}-108: 15\end{array}$ & $\mathrm{~J}$ & $\mathrm{i}$ & BM 486 & $\mathrm{i}$ \\
\hline II & $\begin{array}{l}\text { Br. Libr. Orient. } \\
490 \text {, ff. } 4 \mathrm{r}-29 \mathrm{r}, 18 \mathrm{th} \\
\text { c. } ; 1-107\end{array}$ & $\mathrm{~K}$ & $\mathrm{k}$ & BM 490 & $\mathrm{k}$ \\
\hline II & $\begin{array}{l}\text { Br. Libr. Add. } \\
\text { 24990, ff. 1r-27r, } \\
\text { 18th c.; } 1-106\end{array}$ & $\mathrm{~L}$ & 1 & BM Add. 24990 & 1 \\
\hline I & $\begin{array}{l}\text { Br. Libr. Orient. } \\
\text { 491, ff. } 2 \text { r- }-40 v \text {, } \\
\text { 18th c.;- }-108\end{array}$ & M & $\mathrm{m}$ & BM 491 & $\mathrm{~m}$ \\
\hline II & $\begin{array}{l}\text { Br. Libr. Orient. } \\
492 \text {, ff. } 6 r-33 v, 18 \text { th } \\
\text { c.; } 87 \text { ch.'s }\end{array}$ & $\mathrm{N}$ & $\mathrm{n}$ & BM 492 & $\mathrm{n}$ \\
\hline II & $\begin{array}{l}\text { Br. Libr. Orient. } \\
\text { 499, ff. } 34 \mathrm{r}-63 \mathrm{v} \\
\text { 18th c.; } 1-106\end{array}$ & $\mathrm{O}$ & o & BM 499 & o \\
\hline II & $\begin{array}{l}\text { John Rylands } \\
\text { Libr. Eth. 23, } \\
\text { ff. 1ra-16vc, 18th } \\
\text { c.; } 1-108\end{array}$ & $\mathrm{P}$ & $\mathrm{p}$ & Ryl & $\mathrm{p}$ \\
\hline I & $\begin{array}{l}\text { Berlin Or. Peterm. } \\
\text { II Nachtr. } 29,168 \mathrm{ff} \text {., } \\
\text { 16th c.; } 1-108\end{array}$ & Q & $\mathrm{q}$ & Berl & $\mathrm{q}$ \\
\hline
\end{tabular}




\begin{tabular}{|c|c|c|c|c|c|}
\hline II & $\begin{array}{l}\text { Paris. Abbadie 16, } \\
\text { ff. } 1 \mathrm{r}-22 \mathrm{v}, 19 \text { th c.; } \\
77 \text { ch.'s }\end{array}$ & $\mathrm{R}$ & $\mathrm{r}$ & Abb 16 & \\
\hline II & $\begin{array}{l}\text { Paris. Abbadie } 30 \text {, } \\
\text { ff. } 3 \mathrm{r}-46 \mathrm{v}, 18 \text { th } \\
\text { c.; } 1-108\end{array}$ & S & $\mathrm{s}$ & Abb 30 & \\
\hline I & $\begin{array}{l}\text { Paris, Abbadie } 35 \\
\text { ff. } 1 \mathrm{r}-20 \mathrm{v}, 17 \text { th c.; } \\
1-108\end{array}$ & $\mathrm{~T}$ & $\mathrm{t}$ & Abb 35 & $\mathrm{t}$ \\
\hline I & $\begin{array}{l}\text { Paris, Abbadie } 55 \text {, } \\
\text { ff. } 1 \mathrm{r}-14 \mathrm{v}, 15 / 16 \text { th } \\
\text { c.; } 1-108\end{array}$ & $\mathrm{U}$ & $\mathrm{u}$ & Abb 55 & $\mathrm{u}$ \\
\hline II & $\begin{array}{l}\text { Paris. Abbadie } \\
99,75 \text { ff., 19th } \\
\text { c.; } 1-108\end{array}$ & V & $\mathrm{v}$ & Abb 99 & $\mathrm{v}$ \\
\hline II & $\begin{array}{l}\text { Paris. Abbadie 197, } \\
\text { ff. } 89 \mathrm{r}-123 \mathrm{v}, 19 \text { th } \\
\text { c.; } 1-98\end{array}$ & W & $\mathrm{w}$ & Abb 197 & w \\
\hline II & $\begin{array}{l}\text { Vatic. Eth. } 71,32 \\
\text { ff., } 18 \text { th c.; } 1-108\end{array}$ & $\mathrm{X}$ & $\mathrm{x}$ & Vat 71 & $\mathrm{x}$ \\
\hline II & $\begin{array}{l}\text { Munich cod. aeth. } \\
30,61 \mathrm{ff} ., 18 \text { th } \\
\text { c.; } 1-108\end{array}$ & $\mathrm{Y}$ & $\mathrm{y}$ & Munich 30 & $\mathrm{y}$ \\
\hline II & $\begin{array}{l}\text { Paris. Éth. 114, } \\
\text { ff. } 1-19,17 \text { th } \\
\text { c.; } 1-108\end{array}$ & Z & $\mathrm{z}$ & Paris 114 & \\
\hline II & $\begin{array}{l}\text { Paris. Éth. } 32,63 \\
\text { ff., } 18 \text { th c.; } 1-108\end{array}$ & $Z^{b}$ & $z^{b}$ & Paris 32 & \\
\hline II & $\begin{array}{l}\text { Princeton eth. } 2 \\
\text { (Garret) Dep. } 1468, \\
\text { 18/19th c.; } 1-108\end{array}$ & & $/ \mathrm{a}$ & Garrett MS. & $/ a$ \\
\hline II & $\begin{array}{l}\text { Hamburg. Orient. } \\
\text { 271a (Scrinio } \\
\text { 130), } 68 \text { ff., 18th } \\
\text { c.; } 1-106\end{array}$ & & $/ \mathrm{b}$ & Westenholz MS. & $/ \mathrm{b}$ \\
\hline I & $\begin{array}{l}\text { Cambr. Univ. } \\
\text { Libr. Add. 1570, } \\
\text { ff. } 1 \mathrm{r}-16 \mathrm{v}, 1588 \\
\text { A.D.; } 1-108\end{array}$ & & & (Cambridge MS.) & \\
\hline
\end{tabular}




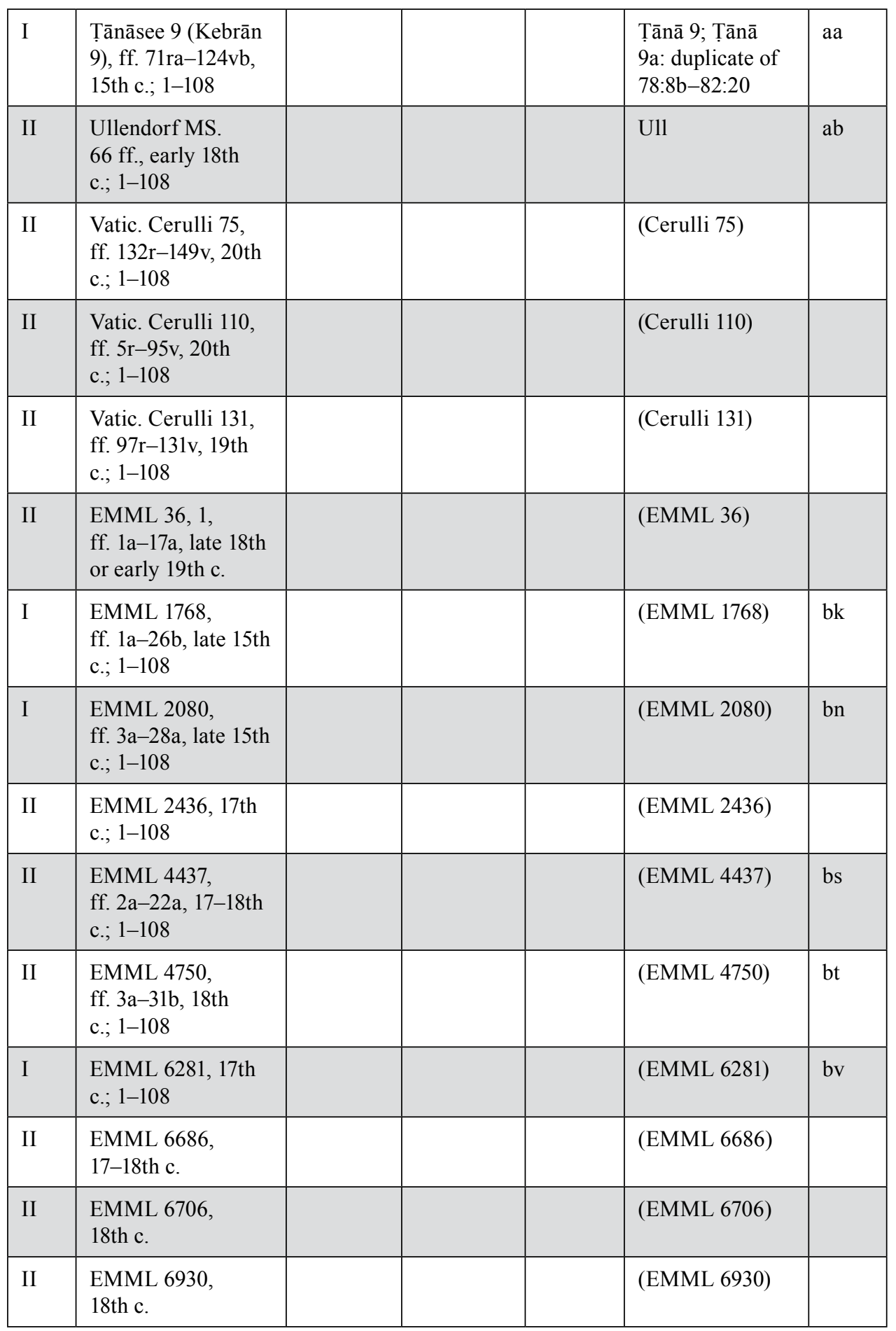




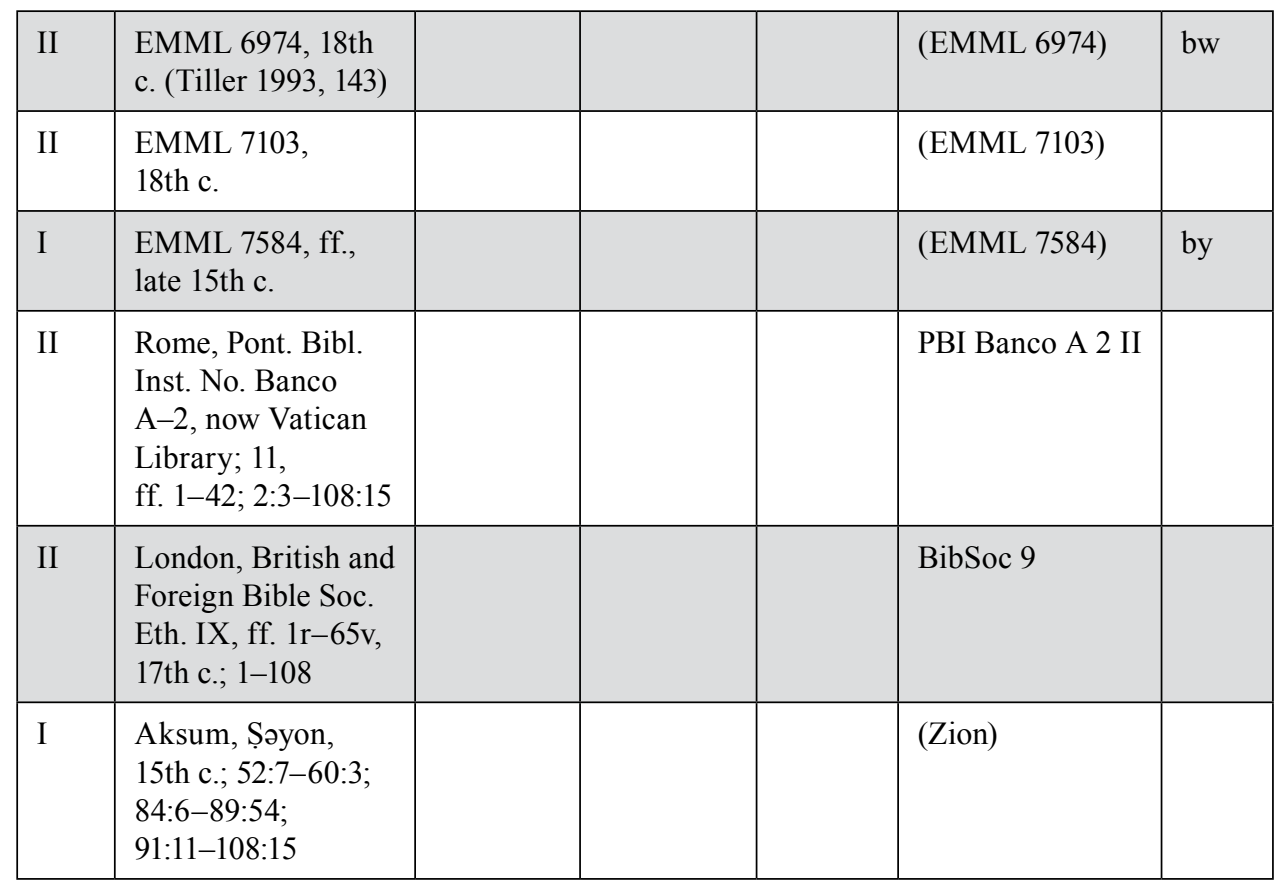

\section{Editio princeps}

Laurence, R. Libri Enoch Prophetae versio aethiopica (Oxford: Parker, 1838). (Ms. Oxford, Bodl. 4 ([Orient. 531], 18th c.; chs. 1-105)

\section{Subsequent Editions Based on a Growing Number of Available Manuscripts}

Charles, R. H. The Ethiopic Version of the Book of Enoch Edited from TwentyThree MSS, together with the Fragmentary Greek and Latin Versions. Anecdota Oxoniensia. Semitic Series 11 (Oxford: Clarendon Press, 1906).

Dillmann, A. Liber Henoch, aethiopice ad quinque codicum fidem editus cum variis lectionibus (Leipzig: Fr. Chr. G. Vogel, 1851).

Flemming, J. Das Buch Henoch: Äthiopischer Text. TUGAL 7/1 (Leipzig: J. C. Hinrichs, 1902). (Two recensions, the older from $15 / 16^{\text {th }} \mathrm{c}$., and its later vulgate revision $\left[17^{\text {th }} \mathrm{c}.\right]$ )

Knibb, M. A. with the assistance of E. Ullendorff, The Ethiopic Book of Enoch: A New Edition in the Light of the Aramaic Dead Sea Fragments. Vol. 1: Text and Apparatus \& Vol. 2: Introduction, Translation and Commentary (Oxford: 
Clarendon Press, 1978). (Photographs of ms. Rylands 23 [Eth. II] with variants, including ms. Țānā 9). Review: J. A. Fitzmyer, JBL (1980): 631-36.

Wendt, K. Das Mașhafa Milād (Liber Nativitatis) und Mașhafa Sellāssēe (Liber Trinitatis) des Kaisers Zar'a Yấqob. II (CSCO 235. SAe 43 (Louvain: Secrétariat du CorpusSCO, 1963) 81-82. (Ms. d'Abbadie 62, 16th c., ff. 154v-155r = 89:20-30)

\section{Studies}

Boccaccini, G. "James Bruce's 'Fourth' Manuscript: Solving the Mystery of the Provenance of the Roman Enoch Manuscript (Vat. et. 71)." JSP 27 (2018): 237-63.

Charles, R. H. "The Ethiopic Manuscripts of Enoch in the British Museum." ExpTim 3 (1890): 135.

Caquot, A. "Recherches de syntaxe sur le texte éthiopien d'Énoch." JA 240 (1952): 487-96.

Caquot, A., and P. Geoltrain. "Notes sur le texte éthiopien des 'Paraboles' d'Hénoch." Sem 13 (1963): 39-54.

Conti Rossini, C. "Notice sur les manuscrits éthiopiens de la collection d'Abbadie (Suite)." JA 10 (1912): 5-72.

Conti Rossini, C. "Notice sur les manuscrits éthiopiens de la collection d'Abbadie (Suite)." JA 11 (1913): 5-64.

Erho, T. "New Ethiopic Witnesses to Some Old Testament Pseudepigrapha." BSOAS 76 (2013): 75-97.

Erho, T. M., and L. T. Stuckenbruck. "A Manuscript History of Ethiopic Enoch.” JSP 23 (2013): 87-133.

Hallévi, J. "Recherches sur la langue de la rédaction primitive du livre d'Énoch." $J A 9$ (6ième série) (1867): 352-95.

Isaac, E. "New Light upon the Book of Enoch from Newly-Found Ethiopic Manuscripts." JAOS 103 (1983): 399-411.

Isaac, E. "The Oldest Ethiopic Manuscript (K-9) of the Book of Enoch and Recent Studies of the Aramaic Fragments of Qumran Cave 4.' Pages 195-207 in 'Working With No Data': Semitic and Egyptian Studies Presented to Thomas O. Lambdin. Edited by D. M. Golomb and S. T. Hollis (Winona Lake: Eisenbrauns, 1987). Isaac, E. "Textual Problems in 4QEnoch." Pages 426-33 in Dead Sea Scrolls: Fifty Years after their Discovery: Proceedings of the Jerusalem Congress, July 20-25, 1997. Edited by L. H. Schiffman, E. Tov, and J. C. VanderKam (Jerusalem: Israel Exploration Society, 2000).

Milik, J. T., with the collaboration of Matthew Black. The Books of Enoch: Aramaic Fragments of Qumrân Cave 4 (Oxford: Clarendon, 1976), 83-88. 
Piovanelli, P. “Sulla Vorlage aramaica dell'Enoch etiopico.” SCO 37 (1987): 545-94. Piovanelli, P. "Il testo e le traduzioni dell'Enoch etiopico 1976-1987." Hen 10 (1988): 85-95.

Raineri, O. "Aethiopica Bibliothecae Apostolicae Vaticanae." Pages 637-52 in Miscellanea Bibliothecae Apostolicae Vaticanae XI. StT 423 (Città del Vaticano: Biblioteca Apostolica Vaticana, 2004).

Uhlig, S. "Zur Überlieferungsgeschichte des äthiopischen Henochbuches." OrChr 69 (1985 184-93.

Uhlig, S. "Bemerkungen zur Textkritik des äthiopischen Henoch und insbesondere der Epistel Henochs." ZDMG 139 (1989): 21-42.

Ullendorff, E. "An Aramaic 'Vorlage' of the Ethiopic Text of Enoch." Pages 259-67 in Atti del Convegno internazionale di studi Etiopici (Roma 2-4 aprile 1959). Problemi Attuali di Scienza e di Cultura 48 (Rome: Accademia Nazionale dei Lincei, 1960).

Ullendorff, E. "Hebrew, Aramaic, and Greek: The Versions Underlying Ethiopic Translations of Bible and Intertestamental Literature." Pages 249-57 in The Bible World: Essays in Honor of Cyrus H. Gordon. Edited by G. Rendsburg et al. (New York: Ktav Publishing House and The Institute of Hebrew Culture and Education of New York University, 1980).

VanderKam, J. C. "The Textual Base for the Ethiopic Translation of 1 Enoch." Pages 247-62 in "Working With No Data”: Semitic and Egyptian Studies Presented to Thomas O. Lambdin. Edited by D. M. Golomb and S. T. Hollis (Winona Lake, IN: Eisenbrauns, 1987).

\subsection{A Coptic Fragment}

C-Antinoopolitanus. Lower part of a folium, $\mathrm{r}(93: 3-5)-\mathrm{v}(93: 6-8)$, and a small non-inscribed part of the second folium of a parchment codex; two columns on each side; uncial Coptic script of biblical style, Sahidic dialect; 6th or 7th c. The text based on a Greek predecessor is shorter than the Ethiopic version and closer to the Aramaic fragments (4Q212 frg. $213-15$ and frg. 3 i 13). The Coptic manuscript has been lost and any trace of its presence in Italian scientific institutions cannot be found. No photograph exists of the codex.

\section{Editio princeps}

Donadoni, S. "Un frammento della versione copta del 'Libro di Enoch." $\mathrm{AOr}$ 25 (1960): 197-202. 


\section{Subsequent Editions}

Drawnel, H. Qumran Cave 4. The Aramaic Books of Enoch. 4Q201, 4Q202, 4Q204, 4Q205, 4Q206, 4Q207, 4Q212 (Oxford: University Press, 2019), $\S$ 1.3.5. (Text based on Donadoni's article)

\section{Studies}

Milik, J. T., with the collaboration of Matthew Black. The Books of Enoch: Aramaic Fragments of Qumrân Cave 4 (Oxford: Clarendon, 1976), 80-81.

Nickelsburg, G. W. E. 1 Enoch 1. A Commentary on the Book of 1 Enoch, Chapters 1-36; 81-108. Hermeneia (Minneapolis, MN: Fortress, 2001), 15.

Stuckenbruck, L. T. 1 Enoch 91-108. CEJL (Berlin: Walter de Gruyer, 2007), $52-53$.

\subsection{A Latin Excerpt}

L - Ms. Royal 5 E xiii, ff. 79v-80r (106:1-5, 8-13, 15-16, 18). Parchment codex; 2nd or 3rd quarter of the 9th c.; Caroline Latin minuscule written in several hands of continental type (corrections in an English hand of the 10th c., see f. 80v), originating in Brittany, western France. British Library, Western Manuscripts, London. The text of 1 Enoch has been abbreviated and partially reworked.

\section{Editio princeps}

James, M. R. "A Fragment of the Book of Enoch in Latin." Pages 146-50 in Apocrypha Anecdota: A Collection of Thirteen Apocryphal Books and Fragments Now First Edited from Manuscripts. Edited by M. R. James. TS 2/3 (Cambridge: Cambridge University Press, 1893).

\section{Subsequent Editions}

Drawnel, H. Qumran Cave 4: The Aramaic Books of Enoch: 4Q201, 4Q202, 4Q204, 4Q205, 4Q206, 4Q207, 4Q212 (Oxford: University Press, 2019), § 1.3.4 (Pl. XXIII-XXIV). (Photographs published for the first time)

Charles, R. H. The Book of Enoch Translated from Professor Dillmann's Ethiopic Text (Oxford: Clarendon Press, 1893), 373-75. 
Charles, R. H. The Ethiopic Version of the Book of Enoch: Edited from Twenty-Three Mss. together with the Fragmentary Greek and Latin Versions. AO.SS 11 (Oxford: Clarendon Press, 1906), 219-22.

Charles, R. H. The Book of Enoch or 1 Enoch: Translated from the Editor's Ethiopic Text (Oxford: Clarendon Press, 1912), 264-68.

Martin, F. Le livre d'Hénoch: Traduit sur le texte éthiopien. Documents pour l'étude de la Bible (Paris: Letouzey et Ané, 1906), 278-80.

\section{Studies}

Denis, A.-M. Concordance latine des Pseudepigraphes d'Ancien Testament: Concordance, Corpus des textes, Indices (Turnhout: Brepols, 1993).

Lechner-Schmidt, W. Wortindex der lateinisch erhaltenen Pseudepigraphen zum Alten Testament. TANZ 3 (Tübingen: Francke, 1990).

Milik, J. T., with the collaboration of Matthew Black. The Books of Enoch: Aramaic Fragments of Qumrân Cave 4 (Oxford: Clarendon, 1976), 81-82.

Verheyden, J. "Les Pseudépigraphes d'Ancien Testament: Textes latins. À propos d'une concordance." ETL 71 (1995): 383-420, esp. 403-406.

Zahn, T. "Ein Bruchstück der lateinischen Übersetzung des Henochbuches." Geschiche des Neutestamentlichen Kanons: Zweiter Band: Urkunden und Belege zum ersten und dritten Band (Leipzig: A. Deichert, 1892), 797-801.

Zahn, T. "Beigabe: Der griechische und der lateinische Henoch." Forschungen zur Geschichte des neutestamentlichen Kanons und der altkirchlichen Literatur. V Teil (Erlangen: A. Deichert, 1893), 58.

\subsection{A Syriac Excerpt}

S - SOAA 0250(S) Paper codex; West Syriac (serțō) script; dated to 1598 AD; Syriac Orthodox Archbishopric Library, Aleppo, Syria. The manuscript number is cited according to the Hill Museum and Manuscript Library electronic catalogue. The Enoch fragment is found in: f. 5r (Arabic - f. 2r), right margin, 11. 42-69 (6:1-6a, 8); f. 5v (Arabic - f. 2v), left margin, 11. 1-6 (cf. 8:3).

\section{Editio princeps}

Chabot, J.-B. Chronique de Michel le Syrien, Patriarche Jacobite d'Antioche (1166-1199): Tomes 1-3 (traduction), tome 4 (texte syriaque) (Paris: Ernest Leroux, 1899, 1901, 1905, 1910), 4:3-4 (text), 1:7-8 (translation). (The text of 
the Chronicle was published with the use of a hand-made copy of the original, consequently - with transcription errors.)

\section{Subsequent Editions}

Drawnel, H. Qumran Cave 4. The Aramaic Books of Enoch. 4Q201, 4Q202, 4Q204, 4Q205, 4Q206, 4Q207, 4Q212 (Oxford: University Press, 2019), $\S 1.3 .3$, pl. XXI-XXII. (Photographs published for the first time)

Brock, S. P. "A Fragment of Enoch in Syriac.” JTS 19 (1968): 626-31. (The Syriac text has been copied with transcription errors due to a poor quality of Chabot's edition.)

Brock, S. P. “Jewish Traditions in Syriac Sources.” JJS 30 (1979): 212-32, esp. 224.

Yuhanna I. G., ed. Texts and Translations of the Chronicle of Michael the Great. Volume 1: The Edessa-Aleppo Syriac Codex of the Chronicle of Michael the Great. A Publication of St. George Parish and the Edessan Community in Aleppo (Piscataway, NJ: Gorgias Press, 2009). (Color photographs of ms. SOAA 0250[S] furnished by the Hill Museum \& Manuscript Library, Collegeville, MN, USA)

\section{New Testament and Early Christian Literature}

Adler, W. "Enoch in Early Christian Literature." Society of Biblical Literature 1978 Seminar Papers, One Hundred Fourteenth Annual Meeting 18-21 November 1978. Edited by. P. J. Achtemeier. 2 vols. SBLSP 13. (Missoula, MN: Scholars Press, 1978), 1:271-75.

Charles, J. D. "Jude's Use of Pseudepigraphical Source-Material as Part of a Literary Strategy." NTS 37 (1991): 130-45.

Charles, R. H. The Book of Enoch or 1 Enoch: Translated from the Editor's Ethiopic Text (Oxford: Clarendon Press, 1912), LXXXI-CIII.

Dehandschutter, B. "Pseudo-Cyprian, Jude and Enoch: Some Notes on 1 Enoch 1:9." Pages 114-20 in Tradition and Re-Interpretation in Jewish and Early Christian Literature: Essays in Honour of Jürgen C. H. Lebram. Edited by J. W. Van Henten et al. StPB 36 (Leiden: E.J. Brill, 1986).

Lawlor, H. J. "Early Citations from the Book of Enoch.” JP 25 (1897): 164-225. Osburn, C. D. "The Christological Use of I Enoch I. 9 in Jude 14, 15." NTS 23 (1977): 334-41.

Osburn, C. D. "1 Enoch 80:2-8 (67:5-7) and Jude 12-13." CBQ 47 (1985): 296-303. 
Vanbeek, L. H. "The Letter of Jude's Use of 1 Enoch: The Book of the Watchers as Scripture" (PhD. diss., University of South Africa; Pretoria, 1998).

VanderKam, J. C. "1 Enoch, Enochic Motifs, and Enoch in Early Christian Literature." Pages 33-101 in The Jewish Apocalyptic Heritage in Early Christianity. Edited by J. C. VanderKam and W. Adler. CRINT 3/4 (Assen: Van Gorcum, 1996).

Wicker, J. R. "An Analysis of the Use of Noncanonical Literature in Jude and 2 Peter" (PhD diss., Southwestern Baptist Theological Seminary; Fort Worth, TX, 1985), 53-100.

\section{Modern Translations ${ }^{3}$}

Agourides, S. TA AПОКРУФА TH $Г$ ПААAIA $\triangle I A \Theta H K H \Sigma$ (KEIMENA - EI $\Sigma A$ ГЛГАI - ГХOАIA): TOMO $\Sigma$ A (Athens, 1973), 261-382, 532-566.

Beer, G. "Das Buch Henoch.” Pages 217-310 in Die Apokryphen und Pseudepigraphen des Alten Testaments: Zweiter Band: Die Pseudepigraphen des Alten Testaments. Edited by E. Kautzsch (Tübingen: Mohr Siebeck, 1900).

Bonsirven, J. La Bible apocryphe: En marge de l'Ancien Testament (Paris: Arthème Fayard, 1953), 25-77.

Brand, M. T. "1 Enoch.” Pages 1359-1452 in Outside the Bible: Ancient Jewish Writings Related to Scripture. Edited by L. H. Feldman, J. L. Kugel, and L. H. Schiffman. 3 vols. (Philadelphia: The Jewish Publication Society, 2013). Caquot, A. "1 Hénoch.” Pages 463-625 in La Bible: Écrits intertestamentaires. Edited by A. Dupont-Sommer and M. Philonenko (Paris: Gallimard, 1987).

Charles, R. H. The Book of Enoch Translated from Professor Dillmann's Ethiopic Text (Oxford: Clarendon Press, 1893).

Charles, R. H. "The Book of Enoch." Pages 163-281 in The Apocrypha and Pseudepigrapha of the Old Testament: II Pseudepigrapha. Edited by R. H. Charles (Oxford: Clarendon, 1913).

Charles, R. H., and W. O. E. Oesterley. The Book of Enoch (London: S.P.C.K., 1917).

Corriente, F., and A. Piñero. "Libro 1 de Henoc (Etiópico y griego)." Pages 11-143 in Apocrifos del Antiguo Testamento. Tomo IV: Ciclo de Henoch. Edited by A. Díez Macho (Madrid: Ediciones Cristiandad, 1984).

de Sacy, A. I. S. "Notice du Livre d'Enoch." Magasin Encyclopédique, ou Journal des Sciences, des Lettres et des Arts 6/1 (1800): 369-98. (Latin translation of 1 En. 1:1-16:3; 22:5-7; 32:1-6. First modern translation of a portion of Ethiopic Enoch)

Translations that accompany a commentary have been listed in $\S 5$. Most translations, though, are accompanied by an introduction and notes. 
Flemming, J., and L. Radermacher. Das Buch Henoch. GCS 5 (Leipzig: Hinrich, 1901).

Goldschmidt, L. Das Buch Henoch: aus dem Aethiopischen in die ursprünglich hebräische Abfassungs-sprache zurückübersetzt, mit einer Einleitung und Noten versehen (Berlin: Richard Heinrich, 1891).

Isaac, E. "1 (Ethiopic Apocalypse of) Enoch (Second Century B.C. - First Century A.D.): A New Translation and Introduction." Pages 5-89 in The Old Testament Pseudepigrapha: Volume 1: Apocalyptic Literature and Testaments. Edited by J. H. Charlesworth (New York: Doubleday, 1983).

Laurence, R. The Book of Enoch, the Prophet: An Apocryphal Production, Supposed to Have Been Lost for Ages; but Discovered at the Close of the Last Century in Abyssinia now first Translated from an Ethiopic MS in the Bodleian Library (Oxford: J. H. Parker, 1821; 3rd ed., rev. and enl., 1838). (First complete translation of the Ethiopic text in modern times)

Migne, J.-P. "Enoch (Le livre d'Enoch).” Col. 393-514 in Dictionnaire des Apocryphes, ou collection de tous les livres Apocryphes: Tome premier (Paris: J.-P. Migne, 1856).

Knibb, M. A. "1 Enoch.” Pages 169-319 in The Apocryphal Old Testament. Edited by H. F. D. Sparks (Oxford: Oxford University Press, 1985).

Nickelsburg, G. W. E., and James C. Vanderkam. 1 Enoch: A Hermeneia Translation (Minneapolis, MN: Fortress, 2012).

Olson, D. C. Enoch: A New Translation: the Ethiopic Book of Enoch, or 1 Enoch: In Consultation with Archbishop Melkesedek Workeneh (North Richland Hills, TX: BIBAL Press, 2004).

Rosso Ubigli, L. "Frammenti aramaici di Enoc." Pages 669-721 in Apocrifi dell'Antico Testamento. Edited by P. Sacchi. Classici delle religioni. Sezione seconda, Religione ebraica (Torino: Unione Tipografica-Editrice Torinese, 1981).

Rubinkiewicz, R. "Księga Henocha etiopska.” Pages 141-189 in Apokryfy Starego Testamentu. Edited by R. Rubinkiewicz (Warszawa: Vocatio, 2000).

Sacchi, P. "Il libro di Enoc." Pages 467-667 in Apocrifi dell'Antico Testamento. Edited by P. Sacchi. Classici delle religioni: Sezione seconda, Religione ebraica (Torino: Unione Tipografica-Editrice Torinese, 1981).

Schodde, G. H. The Book of Enoch: Translated from the Ethiopic, with Introduction and Notes (Andover: W.F. Draper, 1882).

Stachowiak L. "Fragmenty aramejskie Księgi Henocha." Pages 190-196 in Apokryfy Starego Testamentu. Edited by R. Rubinkiewicz (Warszawa: Vocatio, 2000).

Uhlig, S. Das äthiopische Henochbuch. JSHRZ 5/6. Gütersloh: Gütersloher Verlagshaus, 1984).

Wright, A. T. "First Enoch." Pages 178-296 in vol. 2 of Early Jewish Literature: An Anthology. Edited by B. Embry, R. Herms, and A. T. Wright. 2 vols. (Grand Rapids, MI: Eerdmans, 2018). 


\section{Commentaries}

Black, M. The Book of Enoch or I Enoch: A New English Edition with Commentary and Textual Notes. SVTP 7 (Leiden: Brill, 1985).

Charles, R. H. The Book of Enoch or 1 Enoch: Translated from the Editor's Ethiopic Text (Oxford: Clarendon Press, 1912).

Denis, A.-M. Introduction à la littérature religieuse judéo-hellénistique: Tome I: Pseudépigraphes de l'Ancien Testament (Turnhout: Brepols, 2000), 59-144.

Dillmann, A. Das Buch Henoch (Leipzig: Vogel, 1853).

Hoffmann, A. G. Das Buch Henoch in vollständiger Übersetzung mit fortlaufendem Commentar, ausführlicher Einleitung und erlaüternden Excursen. 2 vols. (Jena: Croeker, 1833, 1838).

Martin, F. Le livre d'Hénoch: Traduit sur le texte éthiopien. Documents pour l'étude de la Bible (Paris: Letouzey et Ané, 1906).

Neugebauer, O. "The 'Astronomical' Chapters of the Ethiopic Book of Enoch (72-82): With Additional Notes on the Aramaic Fragments by Matthew Black." Pages 386-419 in The Book of Enoch or I Enoch: A New English Edition with Commentary and Textual Notes. Edited by M. Black. SVTP 7 (Leiden: E. J. Brill, 1985).

Nickelsburg, G. W. E. 1 Enoch 1: A Commentary on the Book of 1 Enoch, Chapters 1-36; 81-108. Hermeneia (Minneapolis, MN: Fortress, 2001). Reviews: Collins, J. J., DSD 9 (2002): 265-68; M. A.Knibb, JSJ 33 (2002): 437-50; L. T. Stuckenbruck, $R B L$ (2005): 1-12.

Nickelsburg, G. W. E., and J. C. VanderKam. 1 Enoch 2: A Commentary on the Book of 1 Enoch: Chapters 37-82. Hermeneia (Minneapolis, MN: Fortress, 2001). Reviews: J. Ben-Dov, DSD 20 (2013): 143-48; H. Drawnel, BibAn 2 (2012): 363-67.

Chialà, S. Libro delle parabole di Enoc: Testo e commento. StBi 117 (Brescia: Paideia, 1997).

Stuckenbruck, L.T. 1 Enoch 91-108. CEJL (Berlin: Walter de Gruyer, 2007).

\section{Monographs and Studies related to Aramaic Fragments ${ }^{4}$}

Ben-Dov, J. Head of All Years: Astronomy and Calendars at Qumran in Their Ancient Context. STDJ 78 (Leiden: Brill, 2008).

Ben-Dov, J., and W. Horowitz. "The 364-Day Year in Mesopotamia and Qumran.” Meghillot 1 (2003): 3-26 (in Hebrew).

4 The list has been limited to publications considered important, and is necessarily selective. 
Ben-Dov, J., and S. Sanders, eds. Ancient Jewish Sciences and the History of Knowledge in Second Temple Literature (New York: New York University Press, 2014).

Black, M. "The Twenty Angel Dekadarchs at I Enoch 6. 7 and 69. 2." JJS 33 (1982): 227-35.

Boccaccini, G. Beyond the Essene Hypothesis: The Parting of the Ways between Qumran and Enochic Judaism (Grand Rapids, MI: William B. Eerdmans, 1998).

Boccaccini, G., ed. Enoch and Qumran Origins. New Light on a Forgotten Connection (Grand Rapids, MI: Eerdmans, 2005).

Coblentz Bautch, K. "Decoration, Destruction and Debauchery: Reflections on 1 Enoch 8 in Light of 4QEn"." DSD 15 (2008): 79-95.

Davidson, M. J. Angels at Qumran. A Comparative Study of 1 Enoch 1-36, 72-108 and Sectarian Writings from Qumran. JSPSup 11 (Sheffield: JSOT Press, 1992).

Dimant, D. “Apocalyptic Texts at Qumran.” Pages 175-91 in The Community of the Renewed Covenant: The Notre Dame Symposium on the Dead Sea Scrolls. Edited by E. C. Ulrich and J. C. VanderKam. CJAn 10 (Notre Dame, IN: University of Notre Dame Press, 1994).

Drawnel H., "Between Akkadian tupšarrūtu and Aramaic ספר: Some Notes on the Social Context of the Early Enochic Literature." RevQ 24 (2010): 373-403.

Drawnel H., "Some Notes on the Aramaic Manuscripts from Qumran and Late Mesopotamian Culture." $\operatorname{RevQ} 26$ (2013): 145-67.

Drawnel H. "1 Enoch 73:4-8 and the Aramaic Astronomical Book." Pages 687-704 in A Teacher for All Generations: Essays in Honor of James C. VanderKam. Edited by E. F. Mason et al. JSJSup 153 (Leiden: Brill, 2012).

Drawnel H. "The Mesopotamian Background of the Enochic Giants and Evil Spirits." DSD 21 (2014): 14-38.

Duke, D., and M. Goff. "The Astronomy of the Qumran Fragments 4Q208 and 4Q209.” DSD 21 (2014): 176-210.

Duke, D., and M. Goff. "A Response to Eshbal Ratzon, 'Methodological Issues Concerning the Astronomy of Qumran'.” DSD 23 (2016): 79-87.

Evans, A. "'1 Enoch Book of Watchers' and 'Astronomical Book': Theodicity in the Context of a Proto-Scientific Cosmology." JoSe 26 (2017): 177-93.

Fitzmyer, J. A. "Implications of the New Enoch Literature from Qumran." TS 38 (1977): 332-345.

Flint, P. W. “'Apocrypha,' Other Previously-Known Writings, and 'Pseudepigrapha' in the Dead Sea Scrolls." The Dead Sea Scrolls after Fifty Years: A Comprehensive Assessment. Edited by P. W. Flint and J. C. VanderKam. 2 vols. (Leiden: Brill, 1999), 2:24-66. 
Fröhlich, I. "Les enseignements des Veilleurs dans la tradition de Qumrân." $\operatorname{Rev} Q 13$ (1988): 177-87.

Fröhlich, I. "Theology and Demonology in Qumran Texts." Hen 32 (2010): $101-29$.

Fröhlich, I. "Enmeduranki and Gilgamesh: Mesopotamian Figures in Aramaic Enoch Traditions." Pages 637-53 in A Teacher for All Generations: Essays in Honor of James C. VanderKam. Edited by E. F. Mason et al. 2 vols. JSJSup 153. (Leiden: Brill, 2012).

Fröhlich, I. "Mesopotamian Elements and the Watchers Traditions." Pages 11-24 in The Watchers in Jewish and Christian Traditions. Edited by A. Kim Harkins, K. Coblentz Bautch, and J. C. Endres (Minneapolis, MN: Fortress, 2014).

Fröhlich, I. "Giants and Demons." Pages 97-114 in Ancient Tales of Giants from Qumran and Turfan: Contexts, Traditions, and Influences. Edited by M. J. Goff, L. T. Stuckenbruck, and E. Morano. WUNT 360 (Tübingen: Mohr Siebeck, 2016).

Fuhs, H. F. "Die äthiopische Übersetzung des Henoch: Ein Beitrag zur Apokalyptikforschung der Gegenwart.” BN 8 (1979): 36-56.

García Martínez, F. "Contribution of the Aramaic Enoch Fragments to our Understanding of the Books of Enoch." Pages 45-96 in Qumran and Apocalyptic: Studies on the Aramaic Texts from Qumran. STDJ 9 (Leiden: E.J. Brill, 1992).

García Martínez, F., and E. J. C. Tigchelaar. "The Books of Enoch (1 Enoch) and the Aramaic Fragments from Qumran." RevQ 14 (1989): 131-46.

Glessmer, U. "Horizontal Measuring in the Babylonian Astronomical Compendium MUL.APIN and in the Astronomical Book of 1 En." Hen 18 (1996): 259-82.

Greenfield, J. C., and M. E. Stone. "The Enochic Pentateuch and the Date of the Similitudes." HTR 70 (1977): 51-65.

Heger, P. Challenges to Conventional Opinions on Qumran and Enoch Issues. STDJ 100 (Leiden: Brill, 2012).

Levine, B. A. "From the Aramaic Enoch Fragments: The Semantics of Cosmography." JJS 33 (1982): 311-26.

Kvanvig, H. S. Roots of Apocalyptic: The Mesopotamian Background of the Enoch Figure and of the Son of Man. WMANT 61 (Neukirchen-Vluyn: Neukirchener Verlag, 1988).

Kvanvig, H. S. Primeval History: Babylonian, Biblical, and Enochic. An Intertexual Reading. JSJSup 149 (Leiden: Brill, 2011). Review: M. Goff, DSD 19 (2012): $229-231$.

Milik, J. T. "Problèmes de la littérature hénochique à la lumière des fragments araméens de Qumran." HTR 64 (1971): 333-78. 
Milik, J. T. "Écrits préesséniens de Qumrân: d’Hénoch à Amram.” Pages 91-106 in Qumrân: Sa piété, sa théologie et son milieu. Edited by M. Delcor. BETL (Paris: Duculot, 1978).

Muchowski, P. Komentarze do rękopisów znad Morza Martwego. BZ.TNT 7 (Kraków: Enigma, 2000), 292-98.

Murray R. "The Origin of Aramaic 'ir, Angel." Or 53 (1984): 303-17.

Nickelsburg, G. W. E. "The Epistle of Enoch and the Qumran Literature." JJS 33 (1982): 333-48.

Nickelsburg, G. W. E. "1 Enoch and Qumran Origins: The State of the Question and Some Prospects for Answers." Pages 341-360 in Society of Biblical Literature Seminar Papers Series. Edited by K. H. Richards. SBLSP 25 (Atlanta, GA: Scholars Press, 1986).

Nickelsburg, G. W. E. "The Qumran Fragments of 1 Enoch and Other Apocryphal Works: Implications for the Understanding of Early and Christian Origins." Pages 181-195 in Jewish Civilization in the Hellenistic-Roman Period. Edited by S. Talmon. JSPSup 10 (Sheffield: Sheffield Academic Press, 1991).

Nickelsburg, G. W. E. "The Books of Enoch at Qumran: What We Know and What We Need to Think About." Pages 99-113 in Antikes Judentum und frühes Christentum: Festschrift für Hartmut Stegemann zum 65. Geburtstag. Edited by B. Kollmann et al. BZNW 97 (Berlin: de Gruyter, 1999).

Nickelsburg, G. W. E. "The Nature and Function of Revelation in Enoch, Jubilees, and Some Qumranic Documents." Pages 91-119 in Pseudepigraphic Perspectives: The Apocrypha and Pseudepigrapha in Light of the Dead Sea Scrolls. Edited by E. G. Chazon, M. E. Stone, and A. Pinnick. STDJ 31 (Leiden: E.J. Brill, 1999).

Nickelsburg, G. W. E. "The Parables of Enoch and Manuscripts from Qumran." A Teacher for All Generations: Essays in Honor of James C. VanderKam. Edited by E. F. Mason et al. 2 vols. JSJSup 153 (Leiden: Brill, 2012), 655-68. Olson, D. C. A New Reading of the Animal Apocalypse of 1 Enoch: "All Nations Shall be Blessed": With a New Translation and Commentary. SVTP 24 (Leiden: Brill, 2013).

Peters, D. M. "The Tension between Enoch and Noah in the Aramaic Enoch Texts at Qumran." Hen 29 (2007): 11-29.

Ratzon, E. "The Conception of the Universe in the Book of Enoch" (Ph.D. diss.: Tel Aviv University, 2015) (in Hebrew).

Ratzon, E. "The Gates Cosmology of the Astronomical Book of Enoch." DSD 22 (2015): 93-111.

Ratzon, E. "Methodological Issues Concerning the Astronomy of Qumran." DSD 22 (2015): 202-09.

Ratzon, E. "Astronomy of Qumran: Further Considerations." DSD 23 (2016): $88-95$. 
Reimer, A. "Rescuing the Fallen Angels: The Case of the Disappearing Angels at Qumran." DSD 7 (2000): 334-53.

Sanders, S. L. "“I Was Shown Another Calculation' (אחזית חשבון אחרן): The Language of Knowledge in Aramaic Enoch and Priestly Hebrew." Pages 69-101 in Ancient Jewish Sciences and the History of Knowledge in Second Temple Literature. Edited by J. Ben-Dov and S. Sanders (New York: New York University Press, 2014).

Segert, S. "Parallelistic Structures in the Aramaic Enoch Fragments." Pages 187-203 in Intertestamental Essays in Honour of Józef Tadeusz Milik. Edited by Z. J. Kapera. QuMog 6 (Kraków: Enigma Press, 1992).

Stökl Ben Ezra, D., and K. Bertholet, eds. Aramaica Qumranica: Proceedings of the Conference on the Aramaic Texts from Qumran in Aix-en-Provence 30 June - 2 July 2008. STDJ 94 (Leiden: Brill, 2010).

Stuckenbruck, L. T., and G. Boccaccini, eds. 1 Enoch and the Synoptic Gospels: Reminiscences, Allusions, Intertextuality. EJL 44 (Atlanta, GA: SBL Press, 2016). Thorndike, J. P. "The Apocalypse of Weeks and the Qumran Sect." RevQ 3 (1961): 163-84.

Tigchelaar, E. J. C. "Some Remarks on the Book of the Watchers, the Priests, Enoch and Genesis, and 4Q208." Hen 24 (2002): 143-45.

Tiller, P. "The 'Eternal Planting' in the Dead Sea Scrolls." DSD 4 (1997): 312-35. VanderKam, J. C. "Some Major Issues in the Contemporary Study of 1 Enoch: Reflections on J. T. Milik's 'The Books of Enoch: Aramaic Fragments of Qumrân Cave 4'." Maarav 3 (1982): 85-97.

VanderKam, J. C. "Studies in the Apocalypse of Weeks (1 Enoch 93:1-10; 91:1117)." CBQ 46 (1984): 511-23.

VanderKam, J. C. Enoch and the Growth of an Apocalyptic Tradition. SBLMS 16 (Washington, DC: The Catholic Biblical Association of America, 1984).

VanderKam, J. C. "The Aramaic Astronomical Book and the Ethiopic Book of the Luminaries." Pages 207-21 in With Wisdom as a Robe: Qumran and Other Jewish Studies in Honour of Ida Fröhlich. Edited by K. D. Dobos and M. Köszeghy (Sheffield: Sheffield Phoenix Press, 2009).

VanderKam, J. C. "The Book of Enoch and the Qumran Scrolls." The Oxford Handbook of the Dead Sea Scrolls. Edited by T. H. Lim and J. J. Collins (Oxford: Oxford University Press, 2010), 254-77.

Vasholz, R. I. "An Additional Note on the 4QEnoch Fragments and 11QTGJob." Maarav 3 (1982): 115-18.

Wacker, M.-T. Weltordnung und Gericht: Studien zu 1 Henoch 22. FB 45 (Würzburg: Echter Verlag, 1982).

White Crawford, S., and C. Wassén, eds. Apocalyptic Thinking in Early Judaism: Engaging with John Collins' 'The Apocalyptic Imagination.' JSJSup 182 (Leiden: Brill, 2018). 